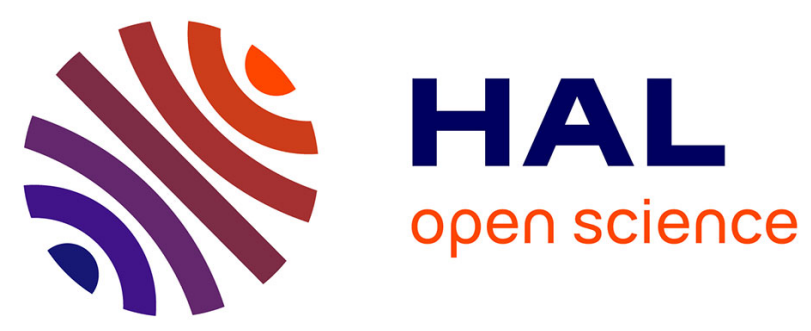

\title{
Modelling the impact of land use change and rainfall seasonality on sediment export from an agricultural catchment of the northwestern European loess belt
}

O. Evrard, Guillaume Nord, Olivier Cerdan, Veronique Souchere, Yves Le Bissonnais, Philippe Bonté

\section{To cite this version:}

O. Evrard, Guillaume Nord, Olivier Cerdan, Veronique Souchere, Yves Le Bissonnais, et al.. Modelling the impact of land use change and rainfall seasonality on sediment export from an agricultural catchment of the northwestern European loess belt. Agriculture, Ecosystems and Environment, 2010, 138 (1-2), pp.83-94. 10.1016/j.agee.2010.04.003 . hal-01197838

\section{HAL Id: hal-01197838 \\ https://hal.science/hal-01197838}

Submitted on 25 May 2020

HAL is a multi-disciplinary open access archive for the deposit and dissemination of scientific research documents, whether they are published or not. The documents may come from teaching and research institutions in France or abroad, or from public or private research centers.
L'archive ouverte pluridisciplinaire HAL, est destinée au dépôt et à la diffusion de documents scientifiques de niveau recherche, publiés ou non, émanant des établissements d'enseignement et de recherche français ou étrangers, des laboratoires publics ou privés. 
1 Modelling the impact of land use change and rainfall seasonality on sediment export

2 from an agricultural catchment of the northwestern European loess belt

3 Olivier Evrard ${ }^{\mathrm{a}}$, Guillaume Nord ${ }^{\mathrm{b}}$, Olivier Cerdan ${ }^{\mathrm{c}}$, Véronique Souchère ${ }^{\mathrm{d}}$,

4 Yves Le Bissonnais ${ }^{\mathrm{e}}$, Philippe Bonté ${ }^{\mathrm{a}}$

5 a Laboratoire des Sciences du Climat et de l'Environnement (LSCE/IPSL), UMR 1572 (CEA/CNRS/UVSQ),

6 Centre de Recherche du CNRS - Bâtiment 12, Avenue de la Terrasse, F-91198 Gif-sur-Yvette Cedex (France)

7 b Institute of Environmental Assessment and Water Research (IDEA), CSIC, Lluis Sole Sabaris s/n, E-08028

8 Barcelona (Spain)

$9{ }^{\mathrm{c}}$ BRGM-Aménagement et risques naturels, Avenue Claude Guillemin 3, BP 6009, F-45060 Orléans (France)

10 INRA, UMR 1048, SAD-APT, F-78000 Thiverval Grignon (France)

$11{ }^{\mathrm{e}}$ INRA, Laboratoire d'étude des Interactions Sol-Agrosystème-Hydrosystème,UMR LISAH, 2 Place Viala, F1234060 Montpellier (France)

13 Correspondence: Olivier Evrard. E-mail : olivier.evrard@1sce.ipsl.fr Tel. +33/1/69.82.35.20.

\section{Abstract}

Soil erosion leads to important environmental problems (e.g. muddy floods, reservoir sedimentation) in cultivated areas of the European loess belt. This study aimed to determine the impact of rainfall seasonality and land use change on soil erosion over the last 40 years in a 94-ha cultivated catchment of Normandy (France). To this end, scenarios representative of the different land use conditions were simulated using the STREAM expert-based erosion model. A 13-yrs long sequence of rainfall events was run with this model. Results showed that erosion increased dramatically after land consolidation $(+168 \%$ on average). Interannual variability of erosion is important. After land consolidation, $79 \%$ of erosion was observed in summer and autumn, even though these seasons only accounted for $58 \%$ of annual rainfall kinetic energy. The bulk of erosion was hence produced by a few intense thunderstorms during this period. Thunderstorms correspond to $5 \%$ of rainfall events and to $15 \%$ of the total rainfall depth, but they generate $51 \%$ of total annual erosion after land consolidation (and up to $57 \%$ of erosion before land consolidation). Confrontation of the STREAM model outputs with the erosion rates modelled based on Cs-137 measurements suggested that soil redistribution within the catchment was very high but that sediment exports from the catchment remained limited (sediment delivery ratio between $1-10 \%)$. Erosion rates derived from Cs-137 measurements showed an important and organised spatial variability, but erosion rates integrated over larger areas remained in the same order of magnitude as those simulated by the STREAM model or were slightly higher. Water erosion would 
hence not be the only process generating erosion within this catchment. In this context, our results show that tillage erosion cannot be neglected to calculate the sediment budget over several decades.

Keywords: Agricultural landscape; erosion; rainfall seasonality; Cesium-137; expert-based model.

\section{Introduction}

During the last decades, a significant increase in environmental problems such as eutrophication, pollution of water bodies and reservoir sedimentation has been observed in Europe, as a result of soil erosion on agricultural land (Boardman and Poesen, 2006). Among these off-site impacts, muddy floods affect numerous villages of northwestern Europe (Boardman et al., 2006) and induce high costs (e.g. 16-172 $\times 10^{6} €$ each year in central Belgium; Evrard et al., 2007a). Regions of intensive agricultural production of the European loess belt, e.g. in Normandy, France (Souchère et al., 2003a), on the South Downs, UK (Boardman et al., 2003) and in central Belgium (Evrard et al., 2007a) are regularly affected by erosion and muddy floods. A severe decline in biodiversity is also outlined in agricultural landscapes of northwestern Europe, as a consequence of agriculture intensification (e.g. Robinson and Sutherland, 2002; Berger et al., 2006).

It is now well established that soil sensitivity to erosion depends on the coincidence of two distributions, namely the driving force of erosion (i.e. rainfall and induced runoff erosivity) and the system resistance (i.e. soil erodibility; Morgan, 2005; Nearing, 2006). Rainfall erosivity depends on the climate area, the seasonal pattern of rainfall and the random occurrence of storms. Soil erodibility, i.e. the sensitivity of soil to detachment by the impact of raindrops and the shearing action of runoff, results from the combination of soil resistance and infiltrability (Knapen et al., 2007a; Knapen et al., 2007b). On the plateaus of the European loess belt, soil erodibility greatly varies throughout the year, because of the decrease in infiltration rate of cultivated soils after tillage/sowing due to surface crusting processes, vegetation growth and the evolution of soil moisture content (Auzet et al, 1990; Le Bissonnais et al., 1998, 2005; Evrard et al., 2009).

The major role played by the interaction between rainfall erosivity and land use on soil erosion at the scale of agricultural catchments has been outlined in several studies (e.g. Cerdan et al., 2002b; Nearing et al., 2005; Evrard et al., 2008a; Valentin et al., 2008). This interplay results in a strong seasonality of erosion during the year. However, to our knowledge, the studies outlining erosion seasonality were restricted to a period of a few years 
or to the impact of storms or extreme events (e.g. Papy and Douyer, 1991; Souchère et al., 2005; Nearing et al., 2005). Furthermore, the few studies that investigated erosion seasonality focused on Mediterranean regions, rather than on northwestern Europe (e.g. Gallart et al., 2005; Lana-Renault, et al., 2007).

Still, in the current context of climate change, there is a need to evaluate the relative contribution of rainfall erosivity and land use change on soil erosion in intensively cultivated areas of northwestern Europe at the scale of several decades. Furthermore, the agricultural regions of northwestern Europe have been characterised by important environmental changes during the last decades. The implementation of the European Common Agricultural Policy (CAP) has, for instance, led to important changes in farming practices, the selection of crop varieties and the landscape structure (e.g. ditch network, field size and shape). Souchère et al. (2003a) outlined that, in certain areas (e.g. Normandy), these modifications occurred very rapidly, within a few years only. These changes greatly modified both the pathways and quantities of runoff and erosion generated in cultivated areas (Van Oost et al., 2000). Operations of land consolidation have particularly modified the pattern of runoff and its lag time to flow across cropland (Evrard et al., 2007b).

When applied over the short-term studies (i.e. from the event to the annual scale), investigations about the driving factors of soil erosion in agricultural land are typically carried out by simulating scenarios using spatially-distributed models, and by comparing the model outputs to field measurements. However, two problems arise when such a methodology is used for several decades. First, it is difficult to find an appropriate erosion model. The model must indeed be spatially-distributed, continuous and require limited input data. Second, field measurements of erosion are rarely available at the catchment scale over such a long period. In order to overcome the modelling problem, we used the STREAM erosion expert-based model (Cerdan et al., 2002a). Even though different types of erosion models have been developed in the past (see e.g. Jetten and Favis-Mortlock, 2006, for a review of models), the ability of empirical models (e.g. USLE) to integrate the dominant processes at the catchment scale is uncertain (Imeson and Kirkby, 1996), whereas process-based models require numerous input data that are generally not available and difficult to measure (Takken et al., 1999). In such a context, it has been shown that expert-based models (e.g. STREAM) offer an alternative and reliable solution in regions where hortonian runoff dominates (Evrard et al., 2009). This type of model focuses on the driving factors of erosion which can be combined by developing tables of decision rules. Furthermore, the application of the selected expert-based model to the catchment where it was initially designed and validated (i.e. the Blosseville 
catchment in Normandy for the STREAM model; Cerdan et al., 2002a) should limit the uncertainties associated with modelling. Various scenarios representative of the different land use and rainfall conditions need to be modelled to derive ranges of sediment export, given long term databases of input data are difficult to derive .

To overcome the lack of field surveys in the past, we used ${ }^{137} \mathrm{Cs}$ measurements to estimate the spatial patterns of erosion and deposition since the 1960s in the Blosseville cultivated catchment. Even though this method is associated with large uncertainties, it can provide an "order of magnitude" of the soil erosion that occurred in intensively cultivated areas over the last four decades (e.g. Sogon et al., 1999; Walling et al., 2002; Van Oost et al., 2005). We also hypothesised that water erosion is the dominant erosion process in this area, and that tillage erosion remains limited.

The main objective of this paper is to model the relative impact of rainfall seasonality and land use change on soil erosion over the last 40 years, in an intensively cultivated catchment of northwestern Europe. First, erosion rates over the whole period are derived from ${ }^{137} \mathrm{Cs}$ measurements. Then, local databases of rainfall, land use and associated soil surface characteristics are analysed to construct various scenarios. These scenarios are then simulated using the STREAM model in order to test the impact of rainfall seasonality and land use change (e.g. land consolidation) on soil erosion, and to compare the simulated erosion rates with the ones derived from ${ }^{137} \mathrm{Cs}$ measurements. Finally, the implications of the reconstructed history of erosion for landscape management within this catchment are discussed.

\section{Materials and methods}

\subsection{Study site}

The Blosseville catchment (94.4 ha) is located in northwestern France (49 $50^{\prime} \mathrm{N}$, $0^{\circ} 47^{\prime} \mathrm{W}$; Normandy; Fig. 1) and is characterised by a humid temperate climate. Mean annual rainfall in the catchment varies between 800 and $900 \mathrm{~mm}$, with a high frequency of low to moderate rainfall in winter (Papy and Douyer, 1991). Mean annual temperature reaches $13^{\circ} \mathrm{C}$, and annual potential evapotranspiration is ca. $500 \mathrm{~mm}$. The catchment has an undulating topography (mean slope of $4.6 \%$ ), the slopes with a gradient between $5-10 \%$ covering less than $10 \%$ of the total surface. Soils are mainly Orthic Luvisols (World Reference Base, 1998) and surface horizons contain at least $60 \%$ silt and $11 \%$ clay (Le Bissonnais et al., 1998). Today, main land uses in the catchment are cropland (96\%) and grassland (4\%). The water 
table is rather deep (>7 m) and is therefore unlikely to generate saturation-excess flow. The catchment is a dry valley, and the fields are undrained.

\subsection{Modelling the erosion rates over a 40 yrs-period based on ${ }^{137}$ Cs measurements \\ ${ }^{137}$ Cs activity was measured on 60 soil profiles sampled along 5 transects within the} catchment in 1998-1999 in order to characterize recent soil redistribution within the catchment. These transects were selected in order to take account of the various topographic settings observed within the catchment (i.e. transects carried out parallel to the principal thalweg directions; transects parallel to the field boundaries and transects along the steepest slope direction). Undisturbed soil cores (having 9-cm diameter) were sampled in the field up to a soil depth of $70 \mathrm{~cm}$. All 60 cores were immediately cut in the field. The first section corresponded to the uppermost $30 \mathrm{~cm}$ of the core (i.e. the ploughed mixed layer). The rest of the cores was then cut in 5-cm sections. All the samples were air-dried during $48 \mathrm{~h}$ at $40{ }^{\circ} \mathrm{C}$, weighted, sieved through a $2 \mathrm{~mm}$ mesh and ground to a fine powder.

${ }^{137} \mathrm{Cs}$ activity was then measured at $661 \mathrm{keV}$ using Germanium gamma-ray detectors (Germanium hyperpure - GeHP, N-type, coaxial model; Eurisys, Lingolsheim, France) during a counting time of $10^{4}-10^{5} \mathrm{~s}$. An initial qualitative assessment was performed on successive sub-samples of each core to determine the maximum depth of the ${ }^{137} \mathrm{Cs}$ signal. Total ${ }^{137} \mathrm{Cs}$ inventory $\left(A_{S} ; \mathrm{Bq} \mathrm{m}^{-2}\right)$ of each core was finally calculated according to Eq. (1).

$$
A_{S}=\sum_{i} A_{i} \times \frac{M_{i}}{S}
$$

where $A_{i}$ is the ${ }^{137} \mathrm{Cs}$ concentration of each sub-sample $i$ of the core containing ${ }^{137} \mathrm{Cs}\left(\mathrm{Bq} \mathrm{kg}{ }^{-1}\right) ; M_{i}$ is the mass $(\mathrm{kg})$ of the soil fine fraction of each sub-sample $i ; S$ is the surface area $\left(\mathrm{m}^{2}\right)$ of the soil core cylinder.

In order to estimate whether soil deposition or erosion occurred in the investigated area, ${ }^{137} \mathrm{Cs}$ inventories were compared with the inventories obtained by sampling in a neighbouring undisturbed site (i.e. an orchard). ${ }^{137} \mathrm{Cs}$ reference value and erosion rates ( $\mathrm{ha}^{-1} \mathrm{yr}^{-1}$ or mm $\mathrm{yr}^{-1}$ ) were calculated using the Cs model developed by Walling and He (1997). The erosion rates derived using the $\mathrm{Cs}$ model were then averaged over larger areas in order to compare them with the outputs of the STREAM erosion model.

\subsection{Description of the STREAM model}


STREAM (Sealing and Transfer by Runoff and Erosion related to Agricultural Management) is an expert-based runoff and erosion model at the small catchment scale (10 1000 ha). It is spatially-distributed, and lumped at the event-scale (Cerdan et al., 2002a). The model assumes that the following surface characteristics are the main determinants of infiltration and runoff at the field scale: soil surface crusting, surface roughness, total cover (crops and residues) and antecedent moisture content (Cerdan et al., 2002a). These characteristics are set for each field using classification rules developed by Le Bissonnais et al. (2005). A table is then used to assign a steady-state (i.e. the constant infiltration rate that is reached during prolonged rainfall) infiltration rate value to each combination of these soil surface characteristics. A runoff/infiltration balance $\left(B_{\alpha}\right)$ is then computed for each pixel $\alpha$ (Eq. 2).

$B_{\alpha}=R-I R-\left(I_{\alpha} \times t\right)$

Where $R$ is the rainfall depth (mm); IR the amount of rainfall needed to reach soil saturation $(\mathrm{mm})$ derived from rainfall depth during the 48 hours before the event; $I_{\alpha}$ is the steady-state infiltration rate $\left(\mathrm{mm} \mathrm{h}^{-1}\right)$ of the pixel $\alpha$ and $t$ is the rainfall duration (h). Note that negative values of $B_{\alpha}$ correspond to infiltration and positive values to runoff.

For each event, the runoff flow network is then derived by combining two models: (i) a standard topographic runoff model (Moore et al., 1988) based on a DEM and redirecting runoff from one cell to the lowest of its eight neighbours and (ii) a tillage direction model developed by Souchère et al. (1998). Based on the infiltration/runoff balance (Eq. 2) calculated for each pixel, a Visual Basic Application (VBA) programme is then run in ArcGIS to determine flow accumulation at the catchment scale (Cerdan et al., 2002a).

Interrill and concentrated erosion modules have also been integrated into STREAM. Within the interrill erosion module, a table is used to assign a potential sediment concentration value (SC) to each combination of surface characteristics (Cerdan et al., 2002b). At the catchment scale, sediment is transported in proportion of the runoff volumes computed with the STREAM runoff module, and is deposited as a function of topography (vertical curvature, slope gradient), or vegetation cover (see Cerdan et al., 2002c for details).

The module calculating gully erosion within the catchments (Souchère et al., 2003b) is based on slope gradient and parameters influencing runoff velocity or soil resistance (vegetation type, crop cover, soil roughness, soil surface crusting). The performance of the STREAM model to predict erosion was evaluated by Evrard et al. (2009). In this study, the 
Nash-Sutcliffe efficiency criterion varied between $0.85-0.95$ for erosion predictions.

Furthermore, Evrard et al. (2009) showed that errors on sediment export predictions provided by the STREAM model can be estimated as $\leq 30 \%$.

\subsection{Model input dataset}

STREAM requires four datasets to compute runoff and erosion at any point of the catchment. First, a land cover dataset, associating each field of the catchment with the appropriate soil surface characteristics, is needed. Then, the slope and the flow directions are calculated by combining the DEM of the catchment and the tillage direction model. A DEM with $5 \mathrm{~m}$ grid cells is available for the Blosseville catchment. Third, a decision table is required to associate the soil surface characteristics observed in the different fields of the catchment with a steady-state infiltration rate $\left(I_{\alpha}\right)$ and a single potential sediment concentration $\left(S C_{\alpha}\right)$ value. Finally, four parameters characterising the simulated rainfall events must be introduced into the model:

- total rainfall amount $(R A ; \mathrm{mm})$;

- total rainfall effective duration $(R D ; \mathrm{h})$ - we therefore removed the rainfall periods with an intensity lower than $2 \mathrm{~mm} \mathrm{~h}^{-1}$;

- total rainfall amount during the $48 \mathrm{~h}$ before the beginning of the event $\left(A R A_{48 h} ; \mathrm{mm}\right)$;

- maximum 5-min rainfall intensity $\left(I_{\max } 5 \min ; \mathrm{mm} \mathrm{h}^{-1}\right)$.

\subsection{Deriving STREAM input data from local databases}

\section{Rainfall data}

Rainfall has been collected between October 1992 and January 2006 by a $0.2-\mathrm{mm}$ resolution raingauge located at the catchment outlet. We distinguished two rainfall events when there is a period without precipitation of at least 150 minutes between them. A threshold of $1 \mathrm{~mm}$ rainfall was also applied to remove the lowest events from the database.

A $k$-means clustering was then used to classify the rainfall events that occurred within the Blosseville catchment $(n=1948)$ into several groups, based on the four parameters required by $\operatorname{STREAM}\left(R A ; R D ; A R A_{48 h} ; I_{\max } 5 \mathrm{~min}\right)$.

The homogeneity of the groups created by the $k$-means clustering was then checked using a non-parametric Kruskal-Wallis test, given the tested variables were not normal. 
Finally, given Salles et al. (2002) state that rainfall kinetic energy is often used as an indicator of rainfall erosivity, kinetic energy $\left(K E ; \mathrm{J} \mathrm{m}^{-2}\right)$ of each rainfall event was calculated using Eq. 3. This equation was selected because it was based on a raindrop size distribution representative for a wide range of environments.

$$
K E_{m m}=\sum_{i} 8.95+8.44 \operatorname{6g}_{10} I_{i}^{-}
$$

where $K E_{m m}$ is the volume-specific kinetic energy $\left(\mathrm{J} \mathrm{m}^{-2} \mathrm{~mm}^{-1}\right)$ and $I$ is the rainfall intensity at the oneminute time step $\left(\mathrm{mm} \mathrm{h}^{-1}\right)$.

Thirteen hydrologic years (starting in October and ending in September) were extracted from the database (October 1992 - September 2005). We checked if these data were representative for the last 40 years in the region using rainfall data available for four neighbouring meteorological stations operated by Météo France and located within a radius of $10 \mathrm{~km}$ around the catchment. Non-parametric Kruskal-Wallis tests were carried out to compare the rainfall regimes of the different periods.

\section{Land use and associated soil surface characteristics}

The field pattern (i.e. their limits and shapes), the crop types and the soil surface characteristics [soil surface crusting; surface roughness; total cover of crops and residues] required by STREAM were determined each month by visual observations in the Blosseville catchment and in neighbouring sites between 1992 and 2002. In total, a database of 4255 field surveys has been compiled (Joannon, 2004; Le Bissonnais et al., 2005; Souchère et al., 2007). This database was used to associate soil surface characteristics with the most common crops in Upper Normandy. Steady-state infiltration rates $\left(I_{\alpha}\right)$ and potential sediment concentrations $\left(S C_{\alpha}\right)$ were attributed to these combinations of soil surface characteristics using the tables proposed by Cerdan et al. (2002a, 2002b) for Normandy. A classification of runoff risk and interrill erosion risk at the field scale was then applied to the common crops of Upper Normandy, based on these $I_{\alpha}$ and $S C_{\alpha}$ values.

Land consolidation in the Blosseville catchment occurred in 1965. The former field pattern was mapped from a digitised aerial photograph taken on 15 September 1947 (French National Geographical Institute). A visual observation of the photograph allowed the recognition of most land uses at the end of summer within the catchment. The proportions of the different land cover classes were then checked using the available agricultural statistics (French General Agricultural Census) in the neighbouring municipalities. 


\subsection{Deriving the erosion rates from STREAM simulations}

The relative impact of (i) rainfall seasonality, (ii) land use (e.g. land consolidation) on soil erosion were investigated, by simulating two series of scenarios:

(i) At the annual scale, we chose to simulate all the sequence of rainfall events (October 1992 - September 2005) recorded by the raingauge located in the catchment. This provided us a reliable order of magnitude of annual erosion. At the interannual scale, we outlined the impact of seasonality and heavier storms during these years, to determine their relative contribution to the total annual erosion. A single heterogeneous crop distribution representative for the crop rotations implemented after the land consolidation and the associated soil surface characteristics was used to perform this first set of simulations.

(ii) We also compared the land use situation before (a) and after (b) the land consolidation of the catchment carried out in 1965, by simulating the same 13 yrsrainfall sequence (October 1992- September 2005) with the land use situation observed before land consolidation and by comparing the output erosion rates with those obtained in (i).

\section{Results and discussion}

\subsection{Modelling the erosion rates over a 40 yrs-period based on ${ }^{137}$ Cs measurements}

In Blosseville, the ${ }^{137} \mathrm{Cs}$ reference value reached $2184 \pm 128 \mathrm{~Bq} \mathrm{~m}^{-2}$ in 2000 (mean activity and standard deviation derived from the analysis of 6 reference cores). The pattern of soil redistribution within the catchment is highly complex and is not directly influenced by slope steepness and convexity (Fig. 2a-b). Erosion within the catchment is the most intense upslope or in the vicinity of the field boundaries, reaching up to $-3 \mathrm{~mm} \mathrm{yr}^{-1}$. However, a succession of erosion and accumulation areas is observed along the different hillslope transects. In contrast, erosion on the footslopes as well as in the thalweg is lower (up to -1.2 $\mathrm{mm} \mathrm{yr}^{-1}$ ), given sedimentation also takes place at those locations. An area of important soil accumulation is observed in the lower part of the catchment thalweg (between 2.3 and $4 \mathrm{~mm}$ $\left.\mathrm{yr}^{-1}\right)$. This accumulation is also influenced by the former land use pattern. This accumulation area is located just upstream of a former field boundary between arable land and grassland (Fig. 2b). Sediments settle typically in such locations. At the catchment outlet, erosion starts 
303 again, at rather severe local rates $\left(-2--3.1 \mathrm{~mm} \mathrm{yr}^{-1}\right)$. These high rates are explained by runoff concentration in the thalweg, close to the catchment outlet. Overall, ${ }^{137} \mathrm{Cs}$ measurements outline the variability of erosion and accumulation patterns within the catchment. This variability is also due to the combination of processes of interrill and rill erosion. Important soil redistribution occurs within the catchment. Three areas are delineated in the vicinity of the transects and a mean erosion rate is calculated for each area to compare it with the STREAM model outputs (Fig. 2a).

\subsection{Rainfall seasonality in the Blosseville catchment}

In total, 1948 rainfall events (> $1 \mathrm{~mm}$ ) occurred in the catchment between October 1992 and September 2005. This rainfall sequence can be considered as representative for the last 40 years. No significant statistical difference (for monthly, seasonal and annual cumulated rainfall) has been identified when comparing the Blosseville dataset (Table 1) to the ones from the neighbouring Météo France stations using Kruskal Wallis tests.

Rainfall is rather evenly widespread throughout the year (Fig. 3a). There are no important seasonal trends associated with the monthly rainfall depth, except a peak of rainfall in October and a slightly lower rainfall depth in summer (particularly in July). When we focus on rainfall erosivity, clearer seasonal differences can be outlined (Fig. 3b). October is clearly the most erosive month of the year, the average kinetic energy reaching $6113 \mathrm{~J} \mathrm{~m}^{-2}$ in October, compared to a monthly average of $3492 \mathrm{~J} \mathrm{~m}^{-2}$ during the rest of the year. Overall, the 4-months period from September to December concentrates $45 \%$ of the total annual erosivity. February and March are rather dry (ca. $50 \mathrm{~mm}$ of monthly rainfall) and characterised by the lowest rainfall erosivity of the year (ca. $2500 \mathrm{~J} \mathrm{~m}^{-2}$ ).

These trends can be refined by characterising the different types of rainfall events occurring each month. The $k$-means classification allows differentiating three types of events (Fig. 3a; Table 2): (i) rainfall on wet soils; (ii) intense thunderstorms and (iii) low-intensity rainfall on dry soils. (i) Rainfall on wet soils is mostly observed between October and January (33\% of the total rainfall depth during this period), even though similar events are also recorded in the remainder of the year (22\% of the total annual rainfall). Rainfall events occurring on wet soils are generally characterised by a low to moderate intensity (RA of 6.5 $\mathrm{mm} ; I_{\max } 5 \min$ of $10.8 \mathrm{~mm} \mathrm{~h}^{-1}$; Table 2). These events, falling mostly on wet soils, are associated with oceanic fronts coming from the Atlantic. (ii) Intense thunderstorms contribute significantly to the cumulative rainfall depth between May and October (25\% of rainfall 
during this period and $15 \%$ of total annual rainfall). They can be considered as 'extreme' in numerous cases (RA of $15.4 \mathrm{~mm} ; I_{\max } 5 \min$ of $48.1 \mathrm{~mm} \mathrm{~h}^{-1}$; Table 2). These storms are associated with the development of convective cells at the end of spring and in summer. (iii) Finally, rainfall on dry soils corresponds to the bulk of annual rainfall (63\%; Fig. 3b). These long-lasting events are characterised by low intensities (RA of $4.5 \mathrm{~mm} ; I_{\max } 5 \min$ of $8.2 \mathrm{~mm} \mathrm{~h}$ 1; Table 2). They correspond in a certain way to the low "background" rainfall signal.

The contribution of these three classes of events to the annual erosivity is somewhat different (Fig. 3b). For instance, the large contribution of thunderstorms to the average monthly erosivity is particularly important between July and October (29\%), even though these storms are rather infrequent (only $9 \%$ of the events occurring during this period).

\subsection{Land cover and associated soil surface characteristics}

The risk of runoff and interrill erosion was derived from data for the period 1992-2002 for the common crops in Upper Normandy, based on the monthly surveys of soil surface characteristics (Table 3a). For simplicity reasons, the common crops have been regrouped in three classes (winter crops; early spring crops and late spring crops). The class of winter crops mostly consists of winter wheat - Triticum aestivum L. (80\%) and in much lower proportions of oilseed rape (Brassica napus L.) and winter barley (Hordeum vulgaris L.); the class of early spring crops regroups proteaginous pea (Pisum arvense L.) and textile flax (Linum usitatissimum L.); and the class of late spring crops represents corn (Zea mays L.), potatoes (Solanum tuberosum L.) and sugar beets (Beta vulgaris L.).

It must be outlined that this monthly evaluation consists in a simplification of the actual situation observed in the field, given the soil surface characteristics at a given time result from the interaction of the rainfall conditions and the crop system at this time.

Furthermore, farming operations modifying soil surface conditions are not distributed randomly throughout the year. Certain farming practices are indeed concentrated during certain periods of the year (e.g. succession of harvests and sowings between mid-July and mid-November). They lead to important modifications of soil surface characteristics during these periods. In contrast, farming operations are more limited during other periods of the year (e.g. from mid-November to mid-February, because of wet and cold conditions) and rainfall erosivity is therefore the driver of the degradation of the soil surface characteristics during this period. 
The sowing date of the different crops is a very important event, which is unfortunately often undocumented in the field surveys. This date, which depends itself on the local meteorological conditions (i.e. the farmer takes advantage of a dry weather to sow the crops) coincides indeed with the beginning of the soil surface degradation by the action of cumulative rainfall (Table 3a). Soil degradation in autumn is particularly high, given the soil surface is not protected by vegetation. The sowing of wheat generally occurs early in October. The rainfall depth needed for the transition of one soil crusting stage to the next has been determined based on the database compiled. The transition from the initial soil fragmentary structure (i.e. F0 stage) to an altered state (i.e. F11 stage) requires ca. $28 \mathrm{~mm}$ rainfall. The local formation of depositional crusts (i.e. F12 stage) is then observed after ca. $87 \mathrm{~mm}$ additional rainfall. Finally, reaching a continuous state with depositional crusts (i.e. F2 stage) requires ca. $110 \mathrm{~mm}$ additional rainfall. A similar analysis has been performed for spring crops, even though the documented soil surface characteristics are not as homogeneous as for winter cereals (Joannon, 2004).

This evaluation allows outlining the periods sensitive to runoff and soil erosion throughout the year (Table 3c-d). The high risk of interrill erosion is restricted to the period following the crop sowing, whereas a high risk of runoff is widespread all throughout the year.

Land use has undergone important modifications since the 1940s (Fig. 4). Land use in 1947, identified by a visual observation of the aerial photograph, consisted in grassland $(64.6 \%)$, winter cereals (28.4\%) and late spring crops (7\%). After the consolidation in 1965, the mean size of the fields increased by $120 \%$, from 1.0 ha in 1947 to 2.2 ha in 2000 . A dramatic decrease of the surface covered by grassland has rapidly occurred in the 1970s. An increase in the variety of crops has also been observed at this time, with the planting of early spring crops (Fig. 4). The proportion of the different land covers remained rather constant between 1979-2000.

\subsection{Impact of rainfall seasonality on erosion}

To remain consistent with the progressive degradation of soil surface characteristics after crop sowing outlined in section 3.3, we simulated the 13-yrs sequence of rainfall, starting in October and ending in September, to coincide with the annual growth cycle of wheat, which is commonly the most widespread crop in the Blosseville catchment. 
The mean erosion rate reached $276.6 \mathrm{t} \mathrm{yr}^{-1}$ for the heterogeneous crop pattern observed after land consolidation and the 13-yrs study period (Table 4a). Summer and autumn were the most erosive seasons (79\% of the total annual erosion; Table 5a) and erosion was primarily triggered by thunderstorms ( $51 \%$ of erosion; Table $5 b)$.

Inter-annual variability of erosion was high (Table 6; Fig. 5). Annual erosion at the catchment outlet ranged between $133 \mathrm{t}$ in 2003-2004 and $389 \mathrm{t}$ in 2000-2001. There was no correlation between total annual rainfall and total annual erosion $\left(\mathrm{R}^{2}=0.03\right)$. This was illustrated by the situation observed during certain years, e.g. 1995-1996. This hydrologic year was the driest of the entire study period (Fig. 5a). Winter rainfall accounted for only $21 \%$ of the total annual rainfall, but generated $89 \%$ of the annual erosion (Fig. 5b). In contrast, 1994-1995 was the wettest year of the study period (Fig. 5a). Winter rainfall accounted for $45 \%$ of annual rainfall but generated only $18 \%$ of total erosion (Fig. $5 b$ ). These two examples illustrate the crucial importance of simulating a sequence of events, and not only isolate storms. This is particularly true in an agricultural region where erosion results from the combination of soil erodibility, which strongly varies all throughout the year, and rainfall erosivity. The high erosion observed in winter in 1995-1996 is due to the occurrence of rainfall on very crusted soils. Such an important issue could not have been outlined if we worked at the event or even at the annual scale.

Intra-annual variability of erosion is also important (Fig. 5a-b). When correlations are calculated between cumulative rainfall and erosion for the different seasons, it is particularly low during winter $\left(\mathrm{R}^{2}=0.09\right)$, low in summer $\left(\mathrm{R}^{2}=0.24\right)$, but higher in spring $\left(\mathrm{R}^{2}=0.51\right)$ and in autumn $\left(\mathrm{R}^{2}=0.62\right)$. This means that cumulative rainfall is only partly relevant to describe erosion extent in spring and autumn, when rain falls on a soil sparsely covered by vegetation, which can directly lead to erosion. In contrast, in winter, erosion mainly depends on the presence of a soil surface crust, which is formed by cumulative rainfall in autumn. In summer, erosion is triggered by thunderstorms, which is badly reflected by cumulative rainfall. The mean contribution to erosion per storm is indeed the highest in summer (up to $45 \mathrm{t}$ per event; Table 4a). It is important to note that, compared to the mean annual rate, erosion generated by a single event can be very important during certain years (e.g. a single event that occurred in September 1998 generated 164.4 t). Given these results, it is really questionable to envisage the creation of a representative mean hydrologic year to investigate erosion in a given area.

\subsection{Impact of land consolidation on erosion}


Before land consolidation, mean erosion rate reached $103 \mathrm{t} \mathrm{yr}^{-1}$ (Table 4b). Overall, erosion increased importantly after land consolidation (+168\% on average; Table 6$)$. Before land consolidation, summer was already the principal contributing season to erosion $(45.8 \%$; Table 4c). Winter erosion was also more important before land consolidation (23.8\%).

The contribution of thunderstorms to total erosion was also higher before land consolidation, triggering $57 \%$ of erosion (Table 5b). This result confirms that runoff and sediment connectivity within a catchment characterised by a small field pattern was already achieved during heavy rainfall. Muddy floods were indeed already reported in Normandy before 1965 (Papy and Douyer, 1991), but they were less frequent. However, sediment export during extreme events was much lower before land consolidation because of the higher proportion of grassland trapping sediment (Fig. 2a). For instance, according to our model simulations, a 53-mm storm occurring in 5 hours and falling on a dry soil in September generates $41.2 \mathrm{t}$ with the field pattern before land consolidation (vs. $152.7 \mathrm{t}$ afterwards).

Crop pattern before land consolidation was run with the soil surface characteristics observed currently. However, the farming machinery used in the 1950s (e.g. horses pulling ploughshares) induced a lower compaction of the soil. Furthermore, soil loosening was less pronounced at this time. Given the formation of a soil surface crust was probably less rapid and less widespread in the past, the infiltration rate and the potential sediment concentration were probably higher, because of a lower soil cohesion in surface. It is likely that this simplification leads to an overestimation of runoff and an underestimation of interrill erosion. Tillage direction was systematically determined as parallel to the longest length of the fields, which appears to be reasonable.

This means that, even though it is probably overestimated, erosion generation was much lower before the land consolidation. This is due to the very large proportion of grassland within the catchment which mostly infiltrated runon and rainfall, as well as to the heterogeneous pattern of small fields prevailing during this period (Fig. 2b). However, it is important to note that erosion in the area was not negligible before 1965.

\subsection{Comparison with Cs measurements}

If we compare the erosion rates simulated by the model (taking account of $30 \%$ uncertainties on erosion predictions) to the ones derived from the ${ }^{137} \mathrm{Cs}$ measurements, we observe that the erosion rates derived from the Cs measurements are in the same order of magnitude, although their mean values are systematically higher than the ones derived from the STREAM model outputs (Table 7). We hypothesised that water erosion dominates in 
Normandy and the STREAM model simulates only this process. However, the slight underestimation of erosion by modelling compared to ${ }^{137} \mathrm{Cs}$ measurements suggests that tillage erosion also needs to be taken into account if we want to reconstruct the history of erosion within a catchment, at the scale of several decades. If we apply this reflection to our results in the Blosseville catchment, it would mean that even though water erosion generates the bulk of erosion within the catchment, tillage erosion cannot be neglected to calculate the sediment budget over 40 years. Tillage erosion could even locally reach $40 \%$. These figures remain consistent with the ones reported for the whole of Europe by Van Oost et al. (2009).

Overall, the Cs analysis demonstrates that the soil redistribution within the catchment is much higher than sediment export. Sediment delivery ratio of the catchment is indeed rather low (1-10\%). Erosion rates calculated based on Cs measurements constitute local rates of soil loss. In contrast, STREAM outputs provide soil losses at the outlet. This sediment is exported and delivered to the river network. Local redistribution of sediment (up to $50 \mathrm{tha}^{-1}$ $\mathrm{yr}^{-1}$ ) exceeds by far the sediment export rate (a maximum of $4 \mathrm{t} \mathrm{ha}^{-1} \mathrm{yr}^{-1}$ after land consolidation, and even $2 \mathrm{t} \mathrm{ha}^{-1} \mathrm{yr}^{-1}$ before the field pattern reorganisation).

\subsection{General discussion and implications for landscape management}

Our results clearly show that significant erosion mostly occurs when both runoff potential (Table 3c) and rainfall erosivity (Fig. 3b) are the highest, which explains that summer and autumn constitute the most erosive seasons in all the simulated scenarios. We demonstrate the necessity to simulate entire years of rainfall (or at least a sequence of events) to obtain reliable erosion predictions for a given catchment.

To calculate the sediment export from the catchment between 1963 (maximum of radionuclide fallout due to test of thermonuclear bombs) and 2000 (period of soil coring in the field), we can subdivide this period into two parts: (1) the period before land consolidation (that occurred in 1965) and (2) the post-1965 period. For the first period (1963-1965), our simulations give a sediment export of $206 \mathrm{t}$ (given the modelled annual mean reaches $103 \mathrm{t}$ $\mathrm{yr}^{-1}$ and this first period covers two years; Table 6). For the second period (1965-2000), our simulations give $9958 \mathrm{t}$ (taking account of a mean annual erosion reaching $276.6 \mathrm{t} \mathrm{yr}^{-1}$ ). In total, 10,164 t of sediment would hence have been exported from the Blosseville catchment during the entire period. STREAM model outputs do not take account of tillage erosion. However, even though tillage erosion mostly generates soil redistribution within the catchment, it should contribute only very slightly to sediment export from the catchment. If we convert the sediment export into soil loss, the mean value reaches $-0.2 \mathrm{~mm} \mathrm{y}^{-1}$ after 1965 
and $-0.1 \mathrm{~mm} \mathrm{yr}^{-1}$ before this period. Over a period of 40 years, the mean soil loss would then reach $-9 \mathrm{~mm}$ (Table 6). A sediment export from a catchment corresponding to a soil layer of less than $1 \mathrm{~cm}$ over 4 decades can seem to be low. However, when it is exported, this fertile layer leads to numerous problems downstream (e.g. sedimentation in reservoirs, transport of pollutants, eutrophication). Given soil cannot be regenerated at the human life scale, it is important to prevent this soil loss. Consequently, on-site conservation measures should be encouraged to limit soil redistribution within a catchment.

Furthermore, it is demonstrated that sediment exports increased by $168 \%$ after land consolidation, because of the decrease in the area covered by grassland and by the increase in field size (Fig. 2). Erosion is particularly important in the thalweg and close to the field borders. In this context, besides on-site erosion control measures, it is important to promote the installation of small-scale dams, grass buffer strips and grassed waterways along the field borders or across runoff and sediment concentration pathways. These measures allow buffering and releasing gradually runoff and sediment when the infiltration rates of the fields are exceeded (e.g. Fiener et al., 2005; Evrard et al., 2008b). This type of mitigation measures precisely allow coping with erosion during heavy rainfall, to prevent downstream damage. Their installation can also be designed to protect or enhance biodiversity in areas of intensive farming (e.g. Berger et al., 2003). The implementation of these measures should systematically be coordinated by catchment agencies similar to the ones existing in central Belgium and Normandy (e.g. Evrard et al., 2008b).

\section{Conclusions}

This case study in a small cultivated catchment (ca. 100 ha) of the European loess belt (Normandy, France) shows that, over a period of 40 years, soil erosion is very intense within the catchment. It can reach local rates of up to $50 \mathrm{t} \mathrm{ha}^{-1} \mathrm{yr}^{-1}$. However, the bulk of erosion consists of sediment redistribution within the catchment and sediment export to the river network remains limited (up to $4 \mathrm{t} \mathrm{ha}^{-1} \mathrm{yr}^{-1}$ ). Model simulations run for a 13-yrs rainfall sequence allow outlining the increase in erosion $(+168 \%)$ that occurred after land consolidation carried out in 1965. Furthermore, the bulk of annual erosion is systematically generated by thunderstorms (51-57\%) and in summer and autumn (69-79\%). Simulations also show the high variability of erosion, both throughout the year as well as from one year to another. This phenomenon is due to the complex interaction between rainfall erosivity and soil surface characteristics during a storm. It is hence crucial to simulate a long sequence of rainfall events to investigate erosion in a catchment at the scale of several decades. 
543 Confrontation of the model results with the erosion rates derived from Cs-137 measurements

suggests that water erosion may not constitute the only significant erosion process in this area. Tillage erosion cannot hence be neglected to establish sediment budgets in intensively

cultivated catchments at the scale of several decades. An adaptation of the model to integrate topographical changes due to erosion could hence be usefully envisaged. These findings outline the need to apply on-site soil conservation measures to limit soil redistribution within the catchment and to install buffer elements (e.g. small-scale dams, grassed waterways) within the landscape to store sediment and release runoff gradually during storms to protect downstream areas.

\section{Acknowledgements}

This is the LSCE contribution \# X. The authors would like to thank the AREAS (Association Régionale pour l'Etude et l'Amélioration des Sols) and Météo France for providing the rainfall data. They also warmly thank Micheline Eimberck who introduced the LSCE researchers to the erosion scientists involved in the Blosseville catchment. Stéphane Sogon and Véronique Lecomte are gratefully acknowledged for the data collection in the field.

\section{References}

Auzet, A.V., Boiffin, J., Papy, F., Maucorps, J., Ouvry, J.F., 1990. An approach to the assessment of erosion forms, erosion risks on agricultural land in the Northern Paris Basin, France. In: Boardman J, Dearing J, Foster I (Eds.), Soil erosion on agricultural land. Wiley : Chichester, pp. 384-400.

Berger, G., Pfeffer, H., Kächele, H., Andreas, S., Hoffmann, J., 2003. Nature protection in agricultural landscapes by setting aside unproductive areas and ecotones within arable fields (“Infield Nature Protection Spots"). Journal for Nature Conservation 11(3), 221-233.

Berger, G., Kaechele, H., Pfeffer, H. 2006. The greening of the European common agricultural policy by linking the European-wide obligation of set-aside with voluntary agrienvironmental measures on a regional scale. Environmental Science \& Policy 9(6), 509-524.

England: problem and responses. Environmental Science and Policy 6, 69-83. 
Boardman, J., Poesen, J., 2006. Soil erosion in Europe: Major processes, causes and consequences. In : Soil Erosion in Europe (ed. Boardman, J., Poesen, J.), pp. 479-487. Wiley,

Chichester.

Boardman, J., Verstraeten, G., Bielders, C., 2006. Muddy floods. In : Boardman, J., Poesen, J. Soil Erosion in Europe. Wiley, Chichester, pp. 743-755.

Cerdan, O., Couturier, A., Le Bissonnais, Y., Lecomte, V., Souchère, V., 2002a. Incorporating soil surface crusting processes in an expert-based runoff model: Sealing and Transfer by Runoff and Erosion related to Agricultural Management. Catena 46, 189-205.

Cerdan, O., Le Bissonnais, Y., Souchère, V., Martin, P., Lecomte, V., 2002b. Sediment concentration in interrill flow: interactions between soil surface conditions, vegetation and rainfall. Earth Surface Processes Landforms 27, 193-205.

Cerdan, O., Le Bissonnais, Y., Couturier, A., Saby, N., 2002c. Modelling interrill erosion in small cultivated catchments. Hydrological Processes 16(16), 3215-3226.

Evrard, O., Bielders, C.L., Vandaele, K., van Wesemael, B., 2007a. Spatial and temporal variation of muddy floods in central Belgium, off-site impacts and potential control measures. Catena 70, 443-454.

Evrard, O., Persoons, E., Vandaele, K., van Wesemael, B., 2007b. Effectiveness of erosion mitigation measures to prevent muddy floods: A case study in the Belgian loam belt. Agriculture, Ecosystems and Environment 118, 149-158.

Evrard, O., Vandaele, K., Bielders, C.L., van Wesemael, B., 2008a. Seasonal evolution of runoff generation on agricultural land in the Belgian loess belt and implications for muddy flood triggering. Earth Surface Processes \& Landforms 33, 1285-1301.

Evrard, O., Vandaele, K., van Wesemael, B., Bielders, C.L., 2008b. A grassed waterway and earthen dams to control muddy floods from a cultivated catchment of the Belgian loess belt Geomorphology 100(3-4), 419-428. 
1

Evrard, O., Cerdan, O., van Wesemael, B., Chauvet, M., Le Bissonnais, Y., Raclot, D., Vandaele, K., Andrieux, P., Bielders, C., 2009. Reliability of an expert-based runoff and erosion model: application of STREAM to different environments. Catena 78, 129-141.

Fiener, P., Auerswald, K., Weigand, S., 2005. Managing erosion and water quality in agricultural watersheds by small detention ponds. Agriculture, Ecosystems \& Environment 110(3-4), 132-142.

Gallart, F., Balasch, J.C., Regües, D., Soler, M., Castelltort, X., 2005. Catchment dynamics in a Mediterranean mountain environment: the Vallcebre research basins (south eastern Pyrenees) II: temporal and spatial dynamics of erosion and stream sediment transport (Ch. 2). In: Garcia, C., Batalla, R. J. (Eds.), Catchment dynamics and river processes: Mediterranean and other climate regions. Elsevier, pp. 17-29.

Imeson, A.C., Kirkby, M.J., 1996. Scaling up processes and models from the field plot to the watershed and regional areas. Journal of Soil and Water Conservation 51(5), 391-396.

Jetten, V., Favis-Mortlock, D., 2006. Modelling soil erosion in Europe. In : Soil Erosion in Europe (ed. Boardman, J., Poesen, J.), pp. 695-716. Wiley, Chichester.

Joannon, A., 2004. Coordination spatiale des systèmes de culture pour la maîtrise des processus écologiques. Cas du ruissellement érosif dans les bassins versants agricoles du Pays de Caux, Haute-Normandie. Unpublished PhD thesis, Institut National Agronomique ParisGrignon.

Knapen, A., Poesen, J., De Baets, S., 2007a. Seasonal variations in soil erosion resistance during concentrated flow for a loess-derived soil under two contrasting tillage practices. Soil \& Tillage Research 94(2), 425-440.

Knapen, A., Poesen, J., Govers, G., Gyssels, G., Nachtergaele, J., 2007b. Resistance of soils to concentrated flow erosion: A review. Earth Science Reviews 80(1-2), 75-109.

Lana-Renault, N., Latron, J., Regues, D., 2007. Streamflow response and water-table 
646 dynamics in a sub-Mediterranean research catchment (Central Pyrenees). Journal of

1 Hydrology 347 (3-4), 497-507.

Le Bissonnais, Y., Benkhadra, H., Chaplot, V., Fox, D., King, D., Daroussin, J., 1998.

Crusting, runoff and sheet erosion on silty loamy soils at various scales and upscaling from $\mathrm{m}^{2}$ to small catchments. Soil \& Tillage Research $46,69-80$.

653 Le Bissonnais, Y., Cerdan, O., Lecomte, V., Benkhadra, H., Souchère, V., Martin, P., 2005.

654 Variability of soil surface characteristics influencing runoff and interrill erosion. Catena 62, $111-124$

Moore, I.D., Burch, B.J., Mackenzie, D.H., 1988. Topographic effects on the distribution of surface soil water and the location of ephemeral gullies. Transactions of the ASAE 31(4), 1098-1107.

Morgan, R.P.C., 2005. Soil Erosion and Conservation. Third edition. Blackwell Publishing, Oxford.

Nearing, M. A., Jetten, V., Baffaut, C., Cerdan, O., Couturier, A., Hernandez, M., Le

Bissonnais, Y., Nichols, M. H., Nunes, J. P., Renschler, C. S., Souchère, V., Van Oost, K., 2005. Modeling response of soil erosion and runoff to changes in precipitation and cover. Catena 61, 131-154.

Nearing, M. A. 2006. Can soil erosion be predicted? In: Owens, P. (Ed.) Soil Erosion and Sediment Redistribution in River Catchments. CABI Publishing, p. 145-152.

Papy, F., Douyer, C., 1991. Influence des états de surface du territoire agricole sur le déclenchement des inondations catastrophiques. Agronomie 11, $201-215$.

Robinson, R.A., Sutherland, W.J., 2002. Post-war changes in arable farming and biodiversity in Great Britain. Journal of Applied Ecology 39 (1), 157-176. 
678 Salles, C., Poesen, J., Sempere-Torres, D., 2002. Kinetic energy of rain and its functional relationship with intensity. Journal of Hydrology 257 (1-4), 256-270.

Sogon, S., Penven, M.J., Bonté, P., Muxart, T., 1999. Estimation of sediment yield and soil loss using suspended sediment load and ${ }^{137} \mathrm{Cs}$ measurements on agricultural land, Brie Plateau, France. Hydrobiologia 410, 251-61.

Souchère, V., King, D., Daroussin, J., Papy, F., Capillon, A., 1998. Effect of tillage on runoff direction: consequences on runoff contributing area within agricultural catchments. Journal of Hydrology 206, 256-267.

Souchère, V., King, C., Dubreuil, N., Lecomte-Morel, V., Le Bissonnais, Y., Chalat, M., 2003a. Grassland and crop trends: role of the European Union Common Agricultural Policy and consequences for runoff and soil erosion. Environmental Science and Policy 6, 7-16.

Souchère, V., Cerdan, O., Ludwig, B., Le Bissonnais, Y., Couturier, A., Papy, F., 2003b.

Modelling ephemeral gully erosion in small cultivated catchments. Catena 50, 489-505.

Souchère, V., Cerdan, O., Dubreuil, N., Le Bissonnais, Y., King, C., 2005. Modelling the impact of agri-environmental scenarios on runoff in a cultivated catchment (Normandy, France). Catena 61 (2-3), 229-240.

Souchère, V., Sorel, L., Couturier, A., Le Bissonnais, Y., Cerdan, O., 2007. Application du modèle STREAM à l'échelle d'un bassin versant au cours d'un cycle hydrologique. (In French). Report of the French National Institute of Agricultural Research (INRA). http://www.prodinra.inra.fr/prodinra/pinra/data/2007/09/PROD2007afc2f2ca_200709070224 03858.pdf

Takken, I., Beuselinck, L., Nachtergaele, J., Govers, G., Poesen, J., Degraer, G., 1999. Spatial evaluation of a physically based distributed erosion model (LISEM). Catena 37, 431-447. 
709 Valentin, C., Agus, F., Alamban, R., Boosaner, A., Bricquet, J.P., Chaplot, V., de Guzman,

1 T., de Rouw, A., Janeau, J.L., Orange, D., Phachomphonh, K., Do Duy Phai, Podwojewski, P., Ribolzi, O., Silvera, N., Subagyono, K., Thiébaux, J.P., Tran Duc Toan, Vadari, T., 2008. Runoff and sediment losses from 27 upland catchments in Southeast Asia: Impact of rapid land use changes and conservation practices. Agriculture, Ecosystems \& Environment 128 (4), 225-238.

Van Oost, K., Van Muysen, W., Govers, G., Deckers, J., Quine, T.A., 2005. From water to tillage erosion dominated landform evolution. Geomorphology 72 (1-4), 193-203.

World Reference Base, 1998. World Reference Base for Soil Resources. FAO, World Resources Report n84, Rome, Italy.

Van Oost, K., Govers, G., Desmet, P.J.J., 2000. Evaluating the effects of changes in landscape structure on soil erosion by water and tillage. Landscape Ecology 15, 577-589.

Van Oost, K., Cerdan, O., Quine, T.A., 2009. Accelerated sediment fluxes by water and tillage erosion on European agricultural land. Earth Surface Processes \& Landforms 34 (12), $1625-1634$.

Walling, D.E., He, Q., 1997. Models for converting ${ }^{137}$ Cs measurements to estimates of soil redistribution rates on cultivated and uncultivated soils (uncluding software for model implementation). A contribution to the I.A.E.A. co-ordinated research programmes on soil erosion (D1.50.05) and sedimentation (F3.10.01).

Walling, D.E., Russell, M.A., Hodgkinson, R.A., Zhang, Y., 2002.Establishing sediment budgets for two small lowland agricultural catchments in the UK. Catena 47(4), 323-353. 
Table 1

Click here to download Tables: Blosseville_Table1-revised.doc

Table 1. Monthly characteristics of rainfall in Blosseville.

$$
\begin{aligned}
& \begin{array}{l}
\text { Blosseville } \\
(1992-2006)
\end{array} \\
& \text { Rain(mm) Rainy days }
\end{aligned}
$$

\begin{tabular}{lll}
\hline January & 70 & 19 \\
February & 56 & 17 \\
March & 53 & 15 \\
April & 62 & 16 \\
May & 58 & 14 \\
June & 58 & 12 \\
July & 50 & 13 \\
August & 59 & 14 \\
September & 74 & 16 \\
October & 99 & 19 \\
November & 81 & 20 \\
December & 100 & 20
\end{tabular}

Year $\quad 818 \pm 120 \quad 193 \pm 29$

$($ mean $\pm \mathrm{SD})$ 
Table 2. Coordinates of the gravity centres of the rainfall groups as classified by the $k$-means clustering.
Rainfall group
RA (mm)
$\mathrm{RD}(\mathrm{h})$
$\mathrm{ARA}_{48 \mathrm{~h}}(\mathrm{~mm})$
$\operatorname{Imax}-5 \min (\mathrm{mm} / \mathrm{h})$

Low intensity rainfall on dry soils $(n=1462)$

Low intensity rainfall on wet soils $(n=382)$

$4 \quad 5$

Thunderstorms $(n=104)$

6

15

$\begin{array}{lll}5 & 3 & 8 \\ 6 & 21 & 11 \\ 5 & 7 & 48\end{array}$

$R A$ is the rainfall amount; $R D$ is the total rainfall duration; $A R A_{48 h}$ is the antecedent rainfall amount during the $48 \mathrm{~h}$ before the event; Imax-5min is the 5-min maximum rainfall intensity. 
Table 3. Classification of runoff /interrill erosion risk for the common crops in Upper Normandy, and associated STREAM input parameters (steady-state infiltration rates $-I \alpha$ - and potential sediment concentration $-S C \alpha$ ).

\begin{tabular}{|c|c|c|c|c|}
\hline Crop & October & November & December & Janua \\
\hline \multirow{2}{*}{ Winter cereals } & C1-F0-R2 & C1-F11-R1 & C1-F12-R0 & $\mathrm{C} 1-\mathrm{F}$ \\
\hline & Sowing & Soil crusting & Soil crusting & \\
\hline Early spring crops & C2-F2-R0 & C2-F2-R0 & C2-F2-R0 & $\mathrm{C} 1-\mathrm{F}$ \\
\hline Late spring crops & C3-F2-R0 & $\begin{array}{l}\text { C3-F2-R0 } \\
\text { Harvest }\end{array}$ & C3-F2-R0 & \\
\hline \multicolumn{5}{|c|}{ (b) Risk quantification } \\
\hline Very low risk & & $\begin{array}{l}\alpha(\mathrm{mm} / \mathrm{h}) \\
>25\end{array}$ & & $\begin{array}{l}\operatorname{se} \alpha \\
1-10\end{array}$ \\
\hline Low risk & & $15-25$ & & $10-15$ \\
\hline Medium risk & & $5-15$ & & $15-2$ \\
\hline High risk & & $1-5$ & & $25-35$ \\
\hline
\end{tabular}

\begin{tabular}{|c|c|c|c|c|c|c|c|}
\hline February & March & April & May & Jur & July & Aug & September \\
\hline C1-F2-R0 & C2-F2-R0 & C3-F2-R0 & C3-F2-R0 & F2-R0 & C3-F2-R0 & $\begin{array}{l}\mathrm{C} 2-\mathrm{F} 2-\mathrm{R} 0 \\
\text { Harvest }\end{array}$ & $=2-\mathrm{RO}$ \\
\hline $\begin{array}{l}\text { C1-F11-R3 } \\
\text { Sowing }\end{array}$ & $\begin{array}{l}\text { C1-F0-R2 } \\
\text { Soil crusting }\end{array}$ & $\begin{array}{l}\text { C2-F0-R1 } \\
\text { Soil crusting }\end{array}$ & $\begin{array}{l}\text { C3-F12-R1 } \\
\text { Soil crustina }\end{array}$ & C3-F12-R0 & C3-F2-R0 & C3-F2-R0 & C2-F2-R0 \\
\hline $\begin{array}{l}\text { Sowing } \\
\text { C3-F2-R0 }\end{array}$ & $\begin{array}{l}\text { Soil crusting } \\
\text { C3-F2-R0 }\end{array}$ & $\begin{array}{l}\text { Soil crusting } \\
\text { C1-F0-R2 }\end{array}$ & $\begin{array}{l}\text { Soil crusting } \\
\text { C1-F0-R2 } \\
\text { Soil crusting }\end{array}$ & $\begin{array}{l}\text { C1-F11-R1 } \\
\text { Soil crustina }\end{array}$ & $\begin{array}{l}\text { C2-F2-R0 } \\
\text { Soil crustina }\end{array}$ & $\begin{array}{l}\text { Harvest } \\
\text { C3-F2-R0 }\end{array}$ & C3-F2-R0 \\
\hline
\end{tabular}

\section{(c) Runoff risk}

Crop

Winter cereals

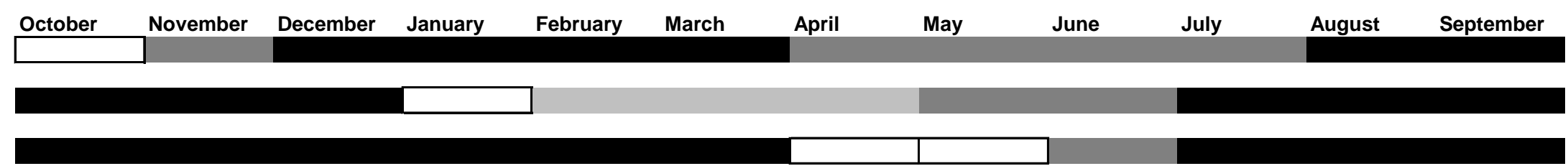

Late spring crops

(d) Interrill erosion risk

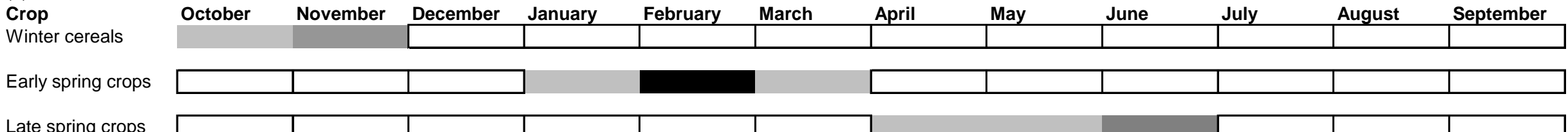

(*) The following soil surface characteristics are documented for each field:

- Soil surface roughness state (height difference between the deepest part of micro-depressions and the lowest point of their divide). R0: 0-1 cm; R1: 1-2 cm; R2: 2-5 cm; R3:

5-10 cm; R4: > $10 \mathrm{~cm}$;

- Crop cover classes (defined after the soil surface percentage covered by canopy or litter). C1: 0-20\%; C2: 21 - 60\%; C3: 61-100\%;

- Soil surface crusting stage. F0: initial fragmentary structure; F11: altered fragmentary state with structural crusts; F12: local appearance of depositional crusts; F2:

continuous state with depositional crusts. 
Table 4. Total erosion at the outlet simulated by the STREAM model for the different land use scenarios [(a) after land consolidation and (b) before land consolidation] for all the rainfall events of the period 1992-2006 $(n=1948)$.

(a) Crop pattern after land consolidation

\begin{tabular}{llll} 
Month & Erosion $(\mathrm{t})$ & \% of total & Mean erosion \\
\hline January & 160 & 4.3 & 8 \\
February & 318 & 8.6 & 24 \\
March & 69 & 1.9 & 5 \\
April & 1.2 & 0 & 0 \\
May & 111 & 3.0 & 7 \\
June & 108 & 2.9 & 7 \\
July & 204 & 5.5 & 11 \\
August & 732 & 19.8 & 46 \\
September & 727 & 19.7 & 25 \\
October & 406 & 11.0 & 9 \\
November & 217 & 5.9 & 7 \\
December & 643 & 17.4 & 17 \\
\end{tabular}

\section{Annual mean $\left({\left.\mathrm{t} \mathrm{yr}^{-1}\right) \mathbf{2 7 6 . 6}}^{-1}\right.$}

Standard deviation $\quad 76.3$

(b) Crop pattern before land consolidation

\begin{tabular}{llll} 
Month & Erosion $(\mathrm{t})$ & $\%$ of total & Mean erosio \\
\hline January & 65 & 4.7 & 4 \\
February & 219 & 16.0 & 18 \\
March & 41 & 3.0 & 5 \\
April & 1 & 0.0 & 0 \\
May & 43 & 3.2 & 11 \\
June & 57 & 4.2 & 7 \\
July & 143 & 10.5 & 10 \\
August & 262 & 19.2 & 11 \\
September & 219 & 16.1 & 8 \\
October & 38 & 2.8 & 8 \\
November & 58 & 4.2 & 7 \\
December & 217 & 15.9 & 6 \\
\hline
\end{tabular}

Annual mean $\left(\mathrm{t} \mathrm{yr}^{-1}\right) \mathbf{1 0 3 . 0}$

Standard deviation $\quad 44.6$ 
Table 5. (a) Seasonal contributions and (b) contribution of different rainfall types to the total erosion simulated at the catchment outlet by the STREAM model (\% of total erosion for all the rainfall events of the period 1992-2006; $n=1948$ ).

(a)

Contribution of

season to total

erosion (\%) Crop pattern

after land consolidation

Crop pattern

before land consolidation

$\begin{array}{lrl}\text { Winter } & 14.8 & 23.8 \\ \text { Spring } & 6.0 & 7.4 \\ \text { Summer } & 45.0 & 45.8 \\ \text { Autumn } & 34.3 & 23.0\end{array}$

(b)

Contribution of

Rainfall type (\%)

Crop pattern

Crop pattern

after land consolidation

before land consolidation

Thunderstorms 51

57

Low intensity rainfall on dry soils $\quad 27 \quad 25$

Low intensity rainfall on wet soils $22 \quad 18$ 
Table 6. Interannual variability of erosion at the Blosseville catchment outlet, as simulated by the STREAM model for the two different field patterns and for the rainfall events of the period 1992-2005 $(n=1948)$.

\begin{tabular}{lllllllll} 
& \multicolumn{3}{c}{ Erosion $\left(\mathrm{yr}^{-1}\right) \mathrm{tha}^{-1} \mathrm{yr}^{-1}$} & \multicolumn{3}{l}{$\mathrm{mm} \mathrm{yr}^{-1}$} & \multicolumn{2}{l}{$\mathrm{mm} 40 \mathrm{yr}^{-1}$} \\
Year & ALC & BLC & ALC & BLC & ALC & BLC & ALC & BLC \\
\hline $1992-1993$ & 207 & 67 & 2.2 & 0.7 & 0.2 & 0.1 & 7 & 2 \\
$1993-1994$ & 201 & 61 & 2.1 & 0.7 & 0.2 & 0.1 & 7 & 2 \\
$1994-1995$ & 325 & 152 & 3.4 & 1.6 & 0.3 & 0.1 & 11 & 5 \\
$1995-1996$ & 260 & 184 & 2.8 & 1.9 & 0.2 & 0.1 & 8 & 6 \\
$1996-1997$ & 346 & 141 & 3.7 & 1.5 & 0.3 & 0.1 & 11 & 5 \\
$1997-1998$ & 313 & 81 & 3.3 & 0.9 & 0.3 & 0.1 & 10 & 3 \\
$1998-1999$ & 356 & 105 & 3.8 & 1.1 & 0.3 & 0.1 & 12 & 3 \\
$1999-2000$ & 235 & 77 & 2.5 & 0.8 & 0.2 & 0.1 & 8 & 2 \\
$2000-2001$ & 390 & 146 & 4.1 & 1.5 & 0.3 & 0.1 & 13 & 5 \\
$2001-2002$ & 218 & 90 & 2.3 & 1.0 & 0.2 & 0.1 & 7 & 3 \\
$2002-2003$ & 257 & 56 & 2.7 & 0.6 & 0.2 & 0.0 & 8 & 2 \\
$2003-2004$ & 135 & 41 & 1.4 & 0.4 & 0.1 & 0.0 & 4 & 1 \\
$2004-2005$ & 354 & 137 & 3.8 & 1.5 & 0.3 & 0.1 & 12 & 4 \\
& & & & & & & & \\
\hline Mean & 276.6 & 103.0 & 2.9 & 1.1 & 0.2 & 0.1 & 9.0 & 3.4 \\
St. Deviation & 76.3 & 44.6 & 0.8 & 0.5 & 0.1 & 0.0 & 2.5 & 1.5 \\
& & & & & & & &
\end{tabular}

ALC: after land consolidation.

BLC: before land consolidation.

$\mathrm{mm} 40 \mathrm{yr}^{-1}$ corresponds to the estimation of total erosion over a period of 40 years. 
Table 7. Comparison of annual erosion rates derived from ${ }^{137} \mathrm{Cs}$ measurements and STREAM outputs for the three areas located within the Blosseville catchment and delineated in Fig. 2.

\# of area Mean annual erosion $\left(\mathrm{mm} \mathrm{yr}^{-1}\right)$ derived from ${ }^{137}$ Cs measurements derived from STREAM outputs

$\begin{array}{lll}1 & 0.6 \pm 0.6 & 0.4 \pm 0.1 \\ 2 & 1.3 \pm 0.4 & 1.1 \pm 0.3 \\ 3 & 1.7 \pm 0.4 & 1.0 \pm 0.3\end{array}$


Fig. 1. Location of the Blosseville catchment in France.

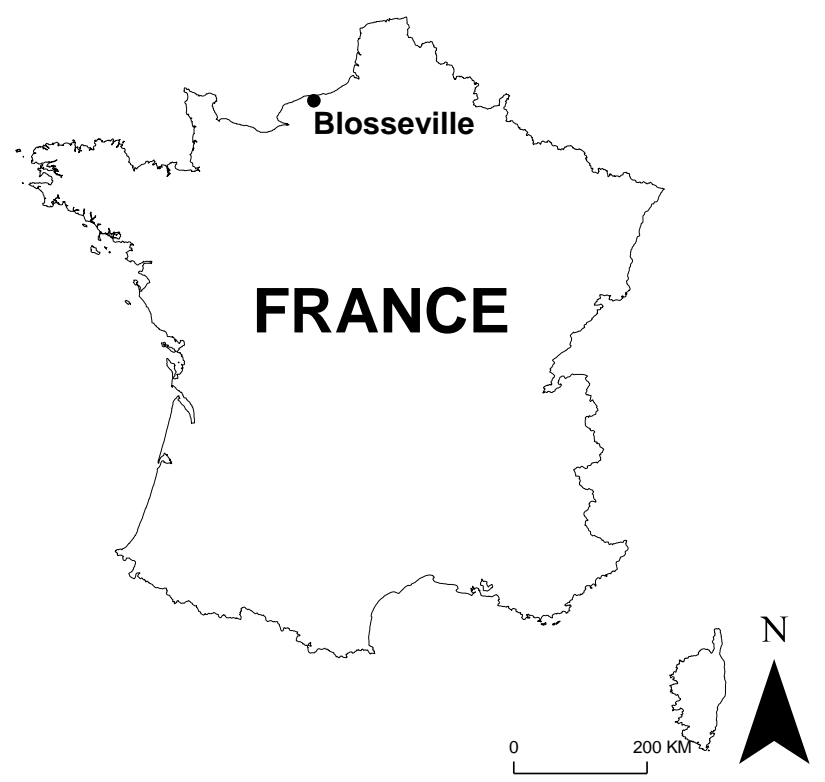


Fig 2. Map of mean annual soil erosion and deposition derived from ${ }^{137} \mathrm{Cs}$ analysis of the 60 soil cores sampled in the Blosseville catchment, as simulated using the Cs model of Walling and He (1997).

(a) Field pattern after land consolidation (situation in 2002). Several areas are delineated to compare the erosion rates derived from ${ }^{137} \mathrm{Cs}$ analysis with the averaged STREAM model outputs.

(b) Field pattern and location of grassland before land consolidation (situation in 1947). 
(a)
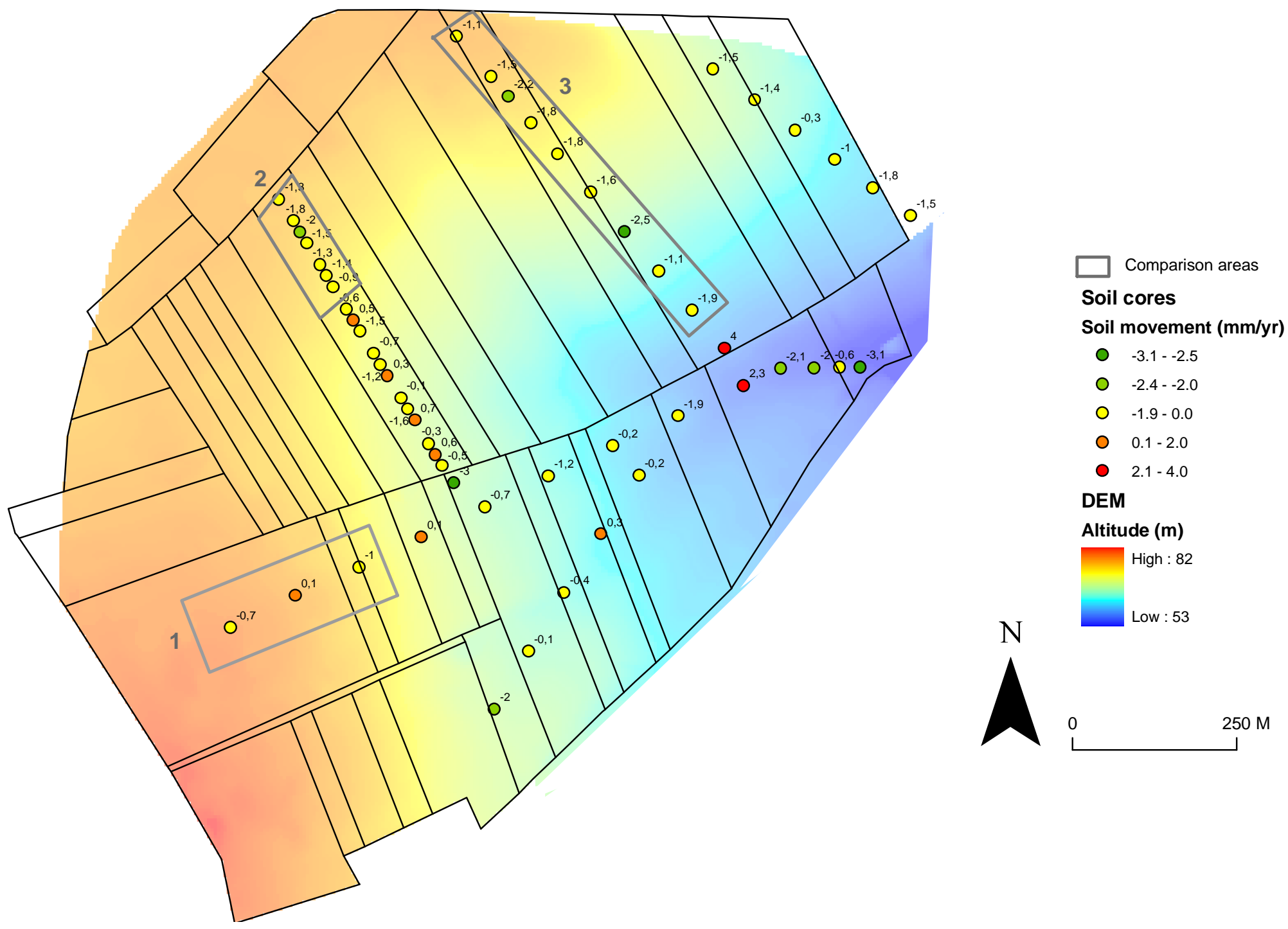

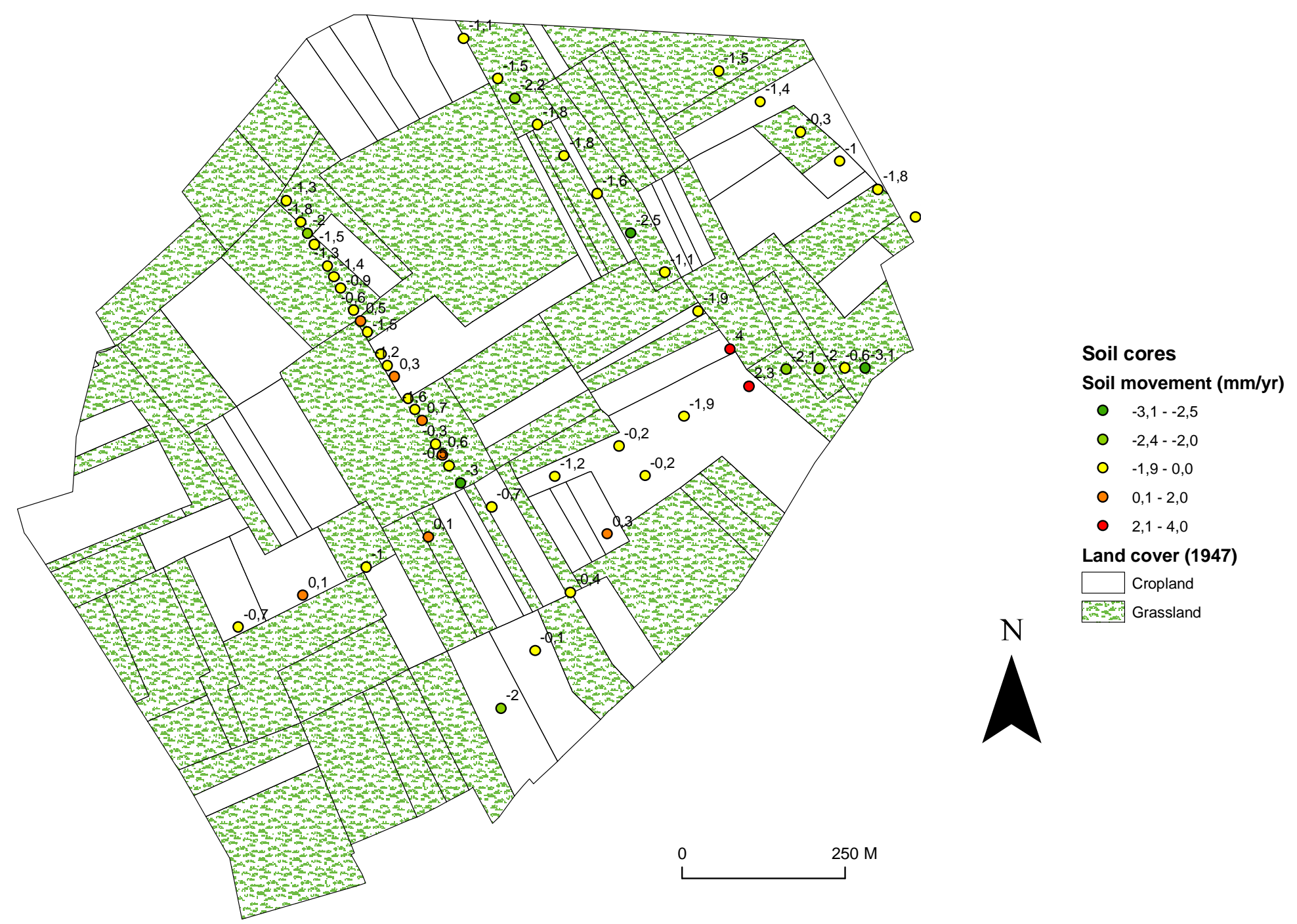

(b) 